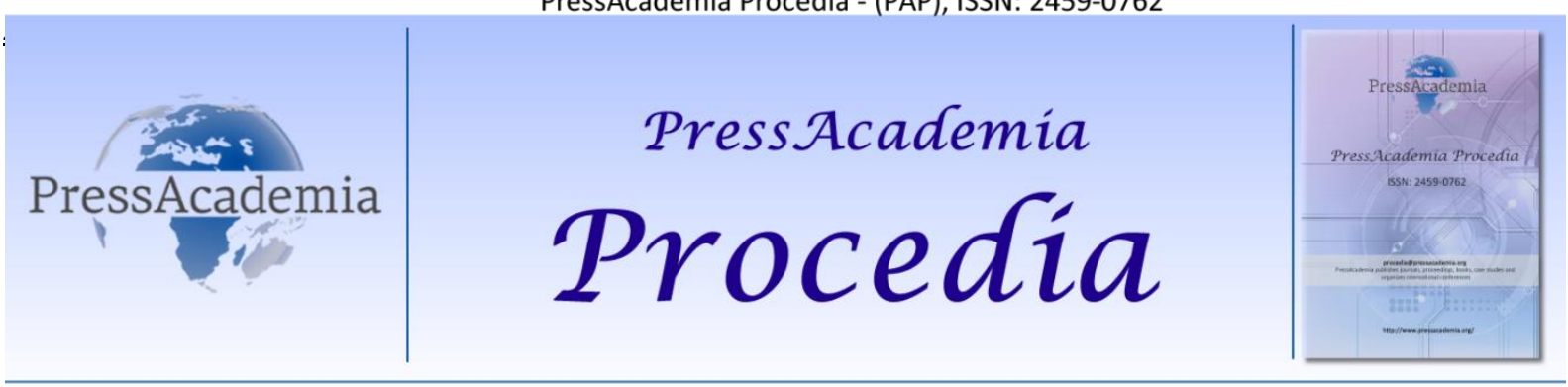

2nd World Conference on Technology, Innovation and Entrepreneurship

May 12-14, 2017, Istanbul, Turkey. Edited by Sefer Şener

\title{
CRITICAL FACTORS FOR OIL PALM PLANTATION WORKERS ACCEPTANCE AND USE OF MECHANIZATION TECHNOVATION TOOLS
}

\author{
DOI: 10.17261/Pressacademia.2017.537 \\ PAP-WCTIE-V.4-2017(29)-p.218-223
}

\author{
Nur Syazwani Mohd Nawi ${ }^{1}$, Baba Md Deros ${ }^{2}$, Norani Nordin ${ }^{3}$, Mohd Nizam Ab Rahman ${ }^{4}$, Ezrin Hani Sukadarin ${ }^{5}$ \\ ${ }^{1}$ Universiti Utara Malaysia. nursyazwani@uum.edu.my \\ ${ }^{2}$ Universiti Kebangsaan Malaysia. hjbaba@ukm.edu.my \\ ${ }^{3}$ Universiti Utara Malaysia. rani@uum.edu.my \\ ${ }^{4}$ Universiti Kebangsaan Malaysia. mnizam@ukm.edu.my \\ ${ }^{5}$ Universiti Malaysia Pahang. ezrin@ump.edu.my
}

\begin{abstract}
Oil palm plantation workers, still rely on manual tools and using mechanization technovation tools has been big issues as they rejected to use. Thus, in emphasizing technovation tools in a human activity, this study aims to examine several factors influencing acceptance and use technovation machine tools in Malaysia based on the revised Unified Theory of Acceptance and Use of Technology (UTAUT) model. A total of 126 oil palm plantation workers answer the questionnaire. This model was analyzed using SPSS technique and conducting reliability test, correlation analysis and regression analysis. The results reveal that performance expectancy, facilitating condition and intention to use were supported as important factors to accept and use of technovation. However, effort expectancy and social influence have been rejected because not significantly influence intention to use technovation. The results of study give implications and suggestions to future researchers and practitioners in order to address problems regarding technovation acceptance.
\end{abstract}

Keywords: UTAUT, technovation, mechanization tools, oil palm plantation workers, Malaysia JEL Codes: O3; Q1

\section{INTRODUCTION}

Technological innovation or called as technovation is part of the leading process of the development country and to become as one of the dominant factors in the success of the organization (Bagherinejad, 2006). It is a process-basedproduct that combines technology and innovation. Therefore, in a well-developed environment nowadays, it is undeniable that the use of technology brings great importance to improve competitiveness and performance of the organization. However, to remain competitive in the market, organizations need to be wise in choosing the right technology and constantly make innovation (Bin \& Salles-filhoa, 2012). The innovation of technology is very important because it has potential in providing more creative solutions when facing many challenges. Technovation also plays a significant role to boost economic development and improve existing technological advances (Liao, Fan, \& Xi, 2011). Existing technovation always do enhancements and performance improvements. This benefit is to ensure successful market of technovation and its benefits can be received by users. It is supported by Govindaraju et al., (2005) who identify technovation as a major agent for development and improvement of productivity, sustained growth in employment and ensuring a better quality of life.

Technovation starting from the emergence of new technology until it is commercialized and widely used. Assistance from mechanization tools is really needed to ensure every work job run smoothly and efficiently. Therefore, acceptance and use technovation in the workplace aims to help ease the burden on workers and increase daily work productivity. In this study, mechanization technovation tools refer to the machinery which is not operated manually. Currently, many technovation tools that have been created from a variety of sources. However, there exist a number of obstacles and issues in regard to 
acceptance and use the technovation namely high cost, complicated utilisations, inconvenient and so on. Such issues will impact the acceptance and use of technovation among potential users of technology. The decision to accept and use technovation tools is depending on the worker's perceived and perception towards the technovation tools (Chi \& Yamada, 2002). Therefore, it is important to know from workers for better understanding how they decide to use or not and what they expect or perceived about the technovation tools. Accordingly, the overall aim of this paper is to solve problems through identifying the critical factors that can influencing acceptance and use technovation among users especially oil palm plantation workers. This will be done by reviewing and analyzing Unified Theory of Acceptance and Use of Technology (UTAUT) model.

\section{LITERATURE REVIEW}

\subsection{Technovation Acceptance and Use}

Acceptance and use of technovation mean the process of integration between science, technology and system-based which focus on the introduction of new technovation to individuals or organization (Bagherinejad, 2006; Nemoto et al., 2010). It is one of the critical components to the success of the country's economic development (Diaconu, 2011; Nemoto et al., 2010). The acceptance and use process include factors that can affect and give impact on individuals and organizations such as ability, environment, education, networks and others. Various factors were considered before committing the technovation acceptance process. According to King, Rollins (1995) and Straub (2009), there are several things to consider when trying to move any technovation tools such as easy, useful for achieving existing requirements and low capital investment. In addition, many researchers agree that consumers are more willing to use technovation tools when its provide more advantage, easy to use and high level of reliability (Mac Callum et al. 2014; Shahbaz et al. 2012; Strong et al. 2013). It can be concluded that factors influencing of technovation acceptance are varied according to the particular situation. Table 1 shows the various determinants of technovation acceptance and uses based on various fields and respondent.

Table 1: Past studies related on factors influencing acceptance and use of technovation

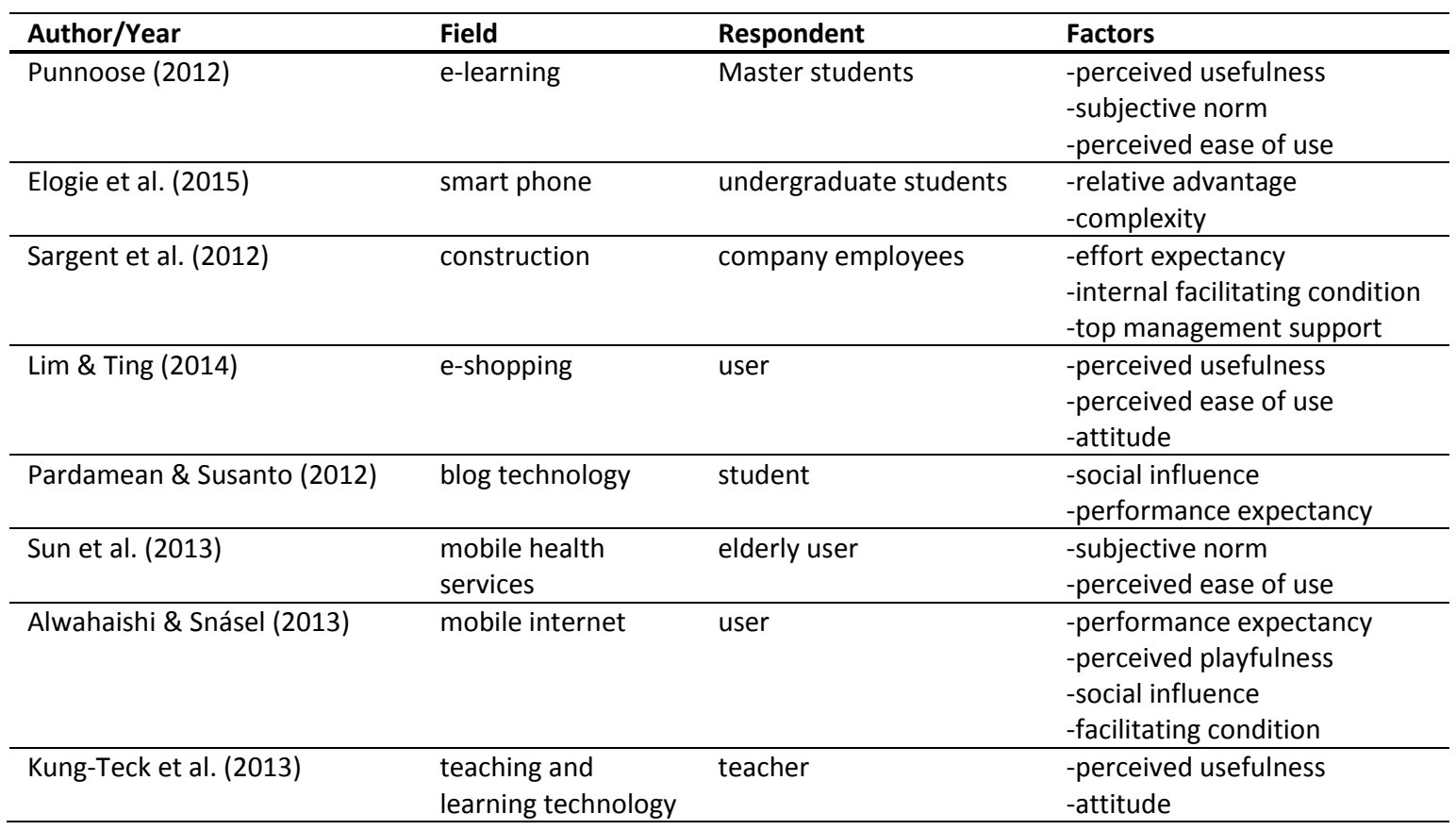

\subsection{The UTAUT Model}

There are many competing models which try to explain human behavior in order to accept new technology. Each of these models brings different influence factors. This study used a UTAUT model as it is a general acceptance of the theory which does not depend on the context. This model is a new model consolidation of all theory and technology acceptance model resulting from a review by Venkatesh et al. (2003). To develop UTAUT model, Venkatesh et al. (2003) have synthesized eight (8) models of user acceptance and motivation. Eight of the theories are Theory of Reasoned Action (TRA), Technology Acceptance Model (TAM), Motivational Model (MM), Theory of Planned Behavior (TPB), Combined Model TPB/TAM (C-TPBTAM), Model of PC Utilization (MPCU), Innovation Diffusion Theory (IDT) and Social Cognitive Theory (SCT). The result of a 
combination of these theories, UTAUT proposes four (4) core constructs that determine the behavioral intention and behavior using which; performance expectancy, effort expectancy, social influence and facilitating condition. This model also has four (4) moderating variables which are age, gender, experience, and voluntariness. UTAUT components (Venkatesh et al. 2003) and the details are contained in Table 2.

Table 2: Description of the UTAUT components

\begin{tabular}{|c|c|}
\hline Component & Description \\
\hline Use behavior & Show real user behavior either accept or reject new technology. \\
\hline Intention to use & $\begin{array}{l}\text { All of the UTAUT factors are the key determinant of behavioral intention or actual } \\
\text { use. }\end{array}$ \\
\hline Performance expectancy & $\begin{array}{l}\text { Refers to the extent to which individual believes that using technology will help } \\
\text { them improve work performance. The construct is same as expected useful in } \\
\text { TAM and comparative advantage in DOI. }\end{array}$ \\
\hline Effort expectancy & $\begin{array}{l}\text { The extent to which an individual believes that using technology, it does not } \\
\text { require any particular effort or in order words, easy to use these technologies. } \\
\text { This construct has the same meaning as perceived easy to use and complexity. }\end{array}$ \\
\hline Social Influence & $\begin{array}{l}\text { Social influence means the extent to which an individual assumed that other } \\
\text { important people believe he/she should use the new technology. }\end{array}$ \\
\hline Facilitating condition & $\begin{array}{l}\text { Individuals believe that an organizational and technical infrastructure exists to } \\
\text { support the use of new technology. }\end{array}$ \\
\hline
\end{tabular}

\section{DATA AND METHODOLOGY}

The framework was developed based on research objectives and problems. This study has made changes to the UTAUT model which not maintain moderators as the original UTAUT model. This is because, the moderators were not relevant to the scope of study such as gender, and since the majority of the workers are men. This study focus on the use of physical technovation tools or mechanization tools in the Malaysian oil palm plantation such as Cantas machine, grabber, mini tractor, badang and much more.The oil palm industry has been chosen as a scope of study because this industry is one of the main drivers of Malaysia's agriculture sector. However, this achievement was overshadowed by a conventional method or manual tools which require a lot of labor. The respondents were oil palm plantation workers who use technovation tools while working. Distribution of the questionnaires was conducted in Peninsular Malaysia and the selection of oil palm plantation in randomly.

Figure 1: Research Model

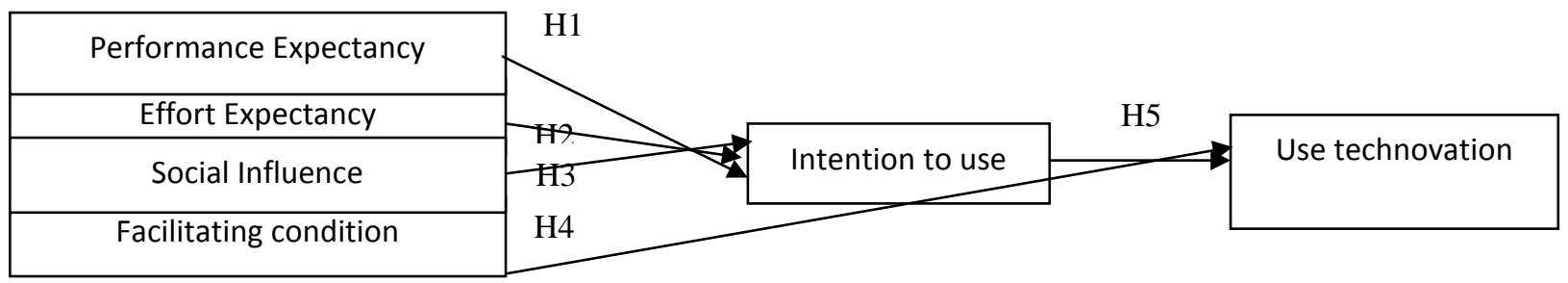

There are five main factors in this research which are performance expectancy, effort expectancy, social influence, facilitating condition, intention to use and use behavior. Research hypotheses for this study are drafted based on research model that has developed in Figure 1. The hypothesis of this study are summarized as follows:

- H1-There will be positive relationship between performance expectancy and intention to use mechanization technovation tools.

- H2- There will be positive relationship between effort expectancy and intention to use mechanization technovation tools.

- H3- There will be positive relationship between social influence and intention to use mechanization technovation tools.

- H4- There will be positive relationship between facilitating condition and use mechanization technovation tools.

- H5- There will be positive relationship between intention to use and use mechanization technovation tools.

The survey consists of two (2) parts namely demographic for part 1 and related on UTAUT for part 2 . The questionnaires using a 5-point Likert scale with a standard answer; (1) strongly disagree, (2) disagree, (3) neutral, (4) agree, (5) strongly agree. The 5-point Likert scale was used to replace the original 7-point Likert scale of UTAUT by Venkatesh et al. (2003) because the answer from respondents can be more genuine and transparent (Adelson \& McCoach 2010). A total of 126 
questionnaires were adopted to analyze the study. Data analysis technique used is the first generation of statistical techniques, Statistical Package for the Social Sciences (SPSS) version 22.0.

\section{FINDINGS AND DISCUSSIONS}

From the results of a study conducted, a total of 126 oil palm plantation workers has answered the questionnaire. All the respondents were male and aged between 19-50 years. Most of the workers have a level of education at primary school level, namely a total of 47 people and a total of 48 secondary schools. However, there are also workers who did not attend school as much as 24 percent. The majority of the workers are married, which is about 65 percent while the rest is a widower and single status.

\subsection{Reliability analysis}

Reliability analysis is used to measure the stability and consistency the instrument either it is reliable to measure research's variables and help to assess goodness of measures. This study measure reliability through Cronbach's coefficient Alpha. According to Cavana et al. (2000), the value of alpha coefficient 0.60 is considered poor but acceptable, in range 0.70 is moderate and over 0.80 is good. From the result of reliability test as stated in Table 3 , it is clear that all the values were falls between 0.70 and 0.88 which considered as moderate and good. Thus, the instruments were valid and reliable to conduct a study.

Table 3: Reliability Statistic

\begin{tabular}{lcc}
\hline Variables & Cronbach's Alpha & Number of items \\
\hline Performance expectancy & 0.88 & 4 \\
Effort expectancy & 0.81 & 4 \\
Social influence & 0.70 & 5 \\
Facilitating condition & 0.71 & 6 \\
Intention & 0.81 & 3 \\
Use technovation & 0.70 & 4 \\
\hline
\end{tabular}

\subsection{Correlation analysis}

Correlation examines the association between two variables and it is measured by the correlation coefficient. Table 4 shows the inter correlations coefficients $(r)$ among variables. All of the correlation coefficients were significantly significant with weak, moderate and strong correlation. The highest correlation is $(r=0.692, p<0.01)$ that is between performance expectancy and use behavior. The correlation between social influence and use technovation presents the weakest association. However, all the correlations of variables have a positive relationship. Therefore, clearly shows that relationship between variables was confirmed and in the same direction as existing UTAUT model.

Table 4 : Correlation of Variables

\begin{tabular}{|c|c|c|c|c|c|c|c|}
\hline & & 1 & 2 & 3 & 4 & 5 & 6 \\
\hline 1 & Performance & 1.00 & & & & & \\
\hline 2 & Effort & $0.450 * *$ & 1.00 & & & & \\
\hline 3 & Social & $0.325 * *$ & $0.401 * *$ & 1.00 & & & \\
\hline 4 & Facilitating & $0.688 * *$ & $0.440 * *$ & $0.417^{* *}$ & 1.00 & & \\
\hline 5 & Intention & $0.480 * *$ & $0.264 * *$ & $0.279 * *$ & $0.559 * *$ & 1.00 & \\
\hline 6 & Use technovation & $0.692 * *$ & $0.332 * *$ & $0.236 * *$ & $0.796 * *$ & $0.603 * *$ & 1.00 \\
\hline
\end{tabular}

** Correlation is significant at the 0.01 level (2-tailed).

\subsection{Regression Analysis}

There are five (5) hypotheses that need to be tested in answering research objectives. In order to test the hypotheses, the researcher performed a regression analysis. This analysis is used to interpret the findings of the study. 
Table 5 : Regression Analysis

\begin{tabular}{lccccc}
\hline \multirow{2}{*}{ Variables } & \multicolumn{4}{c}{ Technovation acceptance and use behavior } \\
\cline { 2 - 6 } & $\begin{array}{c}\text { Unstandardized } \\
\text { beta }\end{array}$ & $\begin{array}{c}\text { Standard } \\
\text { error }\end{array}$ & $\begin{array}{c}\text { Standardized } \\
\text { beta }\end{array}$ & t-stat & Hypothesis \\
\hline Performance expectancy & 0.588 & 0.064 & 0.679 & 9.127 & H1 Supported \\
Effort expectancy & 0.026 & 0.083 & 0.024 & 0.314 & H2 Rejected \\
Social influence & 0.007 & 0.088 & 0.006 & 0.083 & H3 Rejected \\
Facilitating condition & 0.859 & 0.080 & 0.668 & 10.690 & H4 Supported \\
Intention & 0.253 & 0.069 & 0.229 & 3.671 & H5 Supported \\
\hline
\end{tabular}

The results are presented in Table 5. It shows that performance expectancy, facilitating condition and intention to use have a significant and positive relationship. In other words, the hypotheses were supported. Nevertheless, effort expectancy and social influence have a positive impact but not significant on intention. This is contrary to the previous findings by Bakar et al. (2013) and Li et al. (2014). The hypotheses, H2 and H3 were not supported.

\section{CONCLUSION}

The study concludes that performance expectancy, facilitating condition and intention to use affected the acceptance and use technovation tools decision of oil palm workers. In other words, oil palm workers have an intention to use technovation tools if they find that it can help them in enhancing their work performance. They will also have the intention to use if the technovation tools are easy to use and there are other facilities which help them to use it such as training and management support. However, the influence of friends or people around them does not affect the use of technovation tools. From the results, there are several numbers of implications for both theory and practical. In theory, UTAUT model need to be expanded in the different context and specific area of technology acceptance and use behavior. From a practical standpoint, the study can help related parties or industry practitioners in identifying precisely the factors that can promote and increase technovation usage. The study recommended that government should conduct an enforcement campaign and do enforcement to increase utilization of mechanization techovation tools.

\section{REFERENCES}

Adelson, J. L., \& McCoach, D. B. (2010). Measuring the Mathematical Attitudes of Elementary Students: The Effects of a 4-Point or 5-Point Likert-Type Scale. Educational and Psychological Measurement, 70(5), 796-807. http://doi.org/10.1177/0013164410366694

Alwahaishi, S., \& Snásel, V. (2013). Consumers' Acceptance and Use of Information and Communications Technology: A UTAUT and Flow Based Theoretical Model. Journal of Technology Management \& Innovation, 8(2), 9-10. http://doi.org/10.4067/S071827242013000200005

Azlina Abu Bakar, Fahmi Zaidi Abdul Razak, W. S. W. A. (2013). Assessing the effects of UTAUT and self-determination predictor on students continuance intention to use student portal. World Applied Sciences Journal, 21(10), 1484-1489. http://doi.org/10.5829/idosi.wasj.2013.21.10.2920

Bagherinejad, J. (2006). Cultivating technological innovations in Middle Eastern countries: Factors affecting firms ' technological innovation behaviour in Iran. Cross Cultural Management: An International Journal, 13(4), 361-380. http://doi.org/10.1108/13527600610713440

Bin, A., \& Salles-Filhoa, S. (2012). Science, Technology and Innovation Management : Contributions to a Methodological Framework. Journal of Technology Management \& Innovation, 7(2), 73-86.

Cavana, R.Y., Delahaye, B. L. \& Sekaran, U. (2000). Applied Research: Qualitative and Quantitative Methods. Sydney: John Wiley \& Sons Inc

Chi, T., \& Yamada, R. (2002). Factors affecting farmers' adoption of technologies in farming system: A case study in Omon district, Can Tho province, Mekong Delta. Omonrice, 10, 94-100. Retrieved from http://clrri.org/lib/omonrice/10-12.pdf

Diaconu, M. (2011). Technological Innovation : Concept, Process, Typology and Implications in the Economy. Theoretical and Applied Economics, 563(10), 127-144.

Elogie, A. A., Ikenwe, I. J., \& Idubor, I. (2015). Factors influencing the adoption of smartphones by undergraduate students at Ambrose Alli University, Ekpoma, Nigeria. Information Technologist, 12(August). http://doi.org/http://www.ajol.info/index.php/ict/article/view/121119

Govindaraju, V. C., Sundram, V. P. K., Kamil, M. H. M., Ibrahim, Z., \& Ghapar, F. A. (2005). Science, Technology and Innovation in Malaysia: What Do The Key Indicators Suggest? In IRPA Seminar on (Vol.25, p.27). Putrajaya.

King, R. N., \& Rollins, T. (1995). Factors Influencing The Adoption Decision: An Analysis of Adopters and Nonadopters. Journal of Agricultural Education, 36(4). 
Kung-Teck, W., Osman, R., Pauline Swee Choo, G., \& Rahmat, M. K. (2013). Understanding Student Teachers' Behavioural Intention to Use Technology : Technology Acceptance Model (TAM) Validation and Testing. International Journal of Instruction, 6(1).

Li, Q., Yang, D., \& Chen, X. (2014). Predicting Determinants and Moderating Factors of Mobile Phone Data Flow Service Adoption. 2014 Seventh International Joint Conference on Computational Sciences and Optimization, 390-394. http://doi.org/10.1109/CSO.2014.82

Liao, Y., Fan, Y., \& Xi, Y. (2011). A Technological Innovation Management Based on the Audit. International Business Research, 4(2), 170174. http://doi.org/10.5539/ibr.v4n2p170

Lim, W. M., \& Ting, D. H. (2014). E-shopping : An Analysis of the Technology Acceptance Model. Modern Applied Science, 6(4), 49-62. http://doi.org/10.5539/mas.v6n4p49

Mac Callum, K., Jeffrey, L., \& Kinshuk. (2014). Factors Impacting Teachers' Adoption of Mobile Learning. Journal of Information Technology Education, 13, 141-162. Retrieved from http://jite.org/documents/Vol13/JITEv13ResearchP141-162MacCallum0455.pdf

Nemoto, M. C. O., Vasconcellos, E. P. G. de, \& Nelson, R. (2010). The Adoption of New Technology : Conceptual Model and Application. Journal of Technology Management \& Innovation, 5(4).

Pardamean, B., \& Susanto, M. (2012). Assessing User Acceptance toward Blog Technology Using the UTAUT Model. International Journal of Mathematics and Computers in Simulation, 6(27), 203-212.

Punnoose, A. C. (2012). Determinants of intention to use eLearning based on the technology acceptance model. Journal of Information Technology Education:Research, 11(1), 301-337. Retrieved from http://www.scopus.com/inward/record.url?eid=2-s2.084877639303\&partnerlD=tZOtx3y1

Sargent, K., Hyland, P., \& Sawang, S. (2012). Factors Influencing the Adoption of Information Technology in a Construction Business. Australasian Journal of Construction Economics and Building, 12(2), 72-86.

Shahbaz, M., Saleem, W., Syed, A., Aslam, M., Arshad, J., Farooq, A., ... Shaheen, M. (2012). Evaluating the factors responsible for slow rate of technology diffusion in Livestock Sector of South Asia and developing a framework to accelerate this process: A case study using data analysis for Pakistan's Livestock Sector. Life Science Journal, 9(3), 23-30.

Straub, E. T. (2009). Understanding Technology Adoption: Theory and Future Directions for Informal Learning. Review of Educational Research, 79(2), 625-649. http://doi.org/10.3102/0034654308325896

Strong, R., Irby, T., \& Dooley, L. (2013). Factors Influencing Agricultural Leadership Students' Behavioral Intentions: Examining the Potential Use of Mobile Technology in Courses. Journal of Agricultural Education, 54(4), 149-161. http://doi.org/10.5032/jae.2013.04149

Sun, Y., Wang, N., Guo, X., \& Peng, Z. (2013). Understanding the Acceptance of Mobile Health Services: a Comparison and Integration of Alternative Models. Journal of Electronic Commerce Research, 14(2), 183-200.

Venkatesh, V., Morris, M. G., Davis, G. B., \& Davis, F. D. (2003). User Acceptance of Information Technology: Toward a Unified View. MIS Quarterly, 27(3), 425-478. 